BuletinIlmiah Mat. Stat. danTerapannya (Bimaster)

Volume 08, No. 4 (2019), hal 969-978.

\title{
VISUALISASI VARIASI MOTIF SONGKET SAMBAS MENGGUNAKAN METODE L-SYSTEM DAN HIMPUNAN JULIA
}

\author{
Nurul Faseha, Helmi, Mariatul Kiftiah
}

\begin{abstract}
INTISARI
Songket Sambas merupakan salah satu seni budaya Indonesia yang menjadi ciri masyarakat Sambas. Songket Sambas memiliki motif yang menonjol yaitu motif pucuk rebung dihias dan ditaburi motif flora dan fauna. Pola simetris dan pengulangan bentuk pada motif songket dapat digambarkan secara fraktal. Fraktal adalah suatu bentuk geometris yang dapat dipisahkan ke dalam beberapa bagian, dimana masing-masing bagian itu merupakan versi kecil yang berulang. Motif fraktal dapat dibentuk dengan hitungan matematis dan divisualisasi menjadi gambar tertentu menggunakan metode L-System dan himpunan Julia. L-System dibangkitkan dengan segmen garis. Sedangkan himpunan Julia dibangkitkan dengan memanfaatkan bentuk rekursif dari suatu fungsi kuadrat yang melibatkan variabel dan parameter bilangan kompleks. Penelitian ini bertujuan untuk memperoleh motif fraktal songket Sambas tabur awan menggunakan metode L-System dan himpunan Julia. Hasil dari penelitian ini diperoleh bahwa songket Sambas tabur awan dapat dibentuk dari delapan motif untuk metode L-System dan satu motif himpunan Julia.
\end{abstract}

Kata kunci: fraktal, songket, L-System, himpunan Julia.

\section{PENDAHULUAN}

Songket Sambas adalah kain tenun khas masyarakat Sambas, Kalimantan Barat. Songket Sambas biasa disebut kain lunggi dan kain benang emas. Motif songket Sambas diantaranya pucuk rebung, telur bunga cangkringan, rantai emas, mahkota berawan, sabuk rantai berbintang, dan bintang timur [1]. Pola motif pada songket Sambas jika diperhatikan merupakan sebuah motif yang digambar berulang-ulang.

Pola simetris dan pengulangan bentuk pada motif songket dapat digambarkan secara fraktal. Fraktal adalah objek geometri yang tampak memiliki persamaan bentuk yang mewakili bentuk dasar objek itu sendiri jika dilihat dari skala tertentu dan merupakan bagian terkecil dari struktur suatu objek secara keseluruhan [2]. Beberapa contoh fraktal yang umum adalah himpunan Mandelbrot, himpunan Julia, himpunan Cantor, segitiga Sierpinski, karpet Sierpinski, spons Menger dan kurva Koch [3].

Fraktal dapat dibentuk menggunakan metode L-System, dan himpunan Julia. Lindenmayer System atau sering disebut L-System adalah metode yang dikonstruksi dari suatu objek sederhana berupa segmen garis [4]. Langkah-langkah membangkitkan objek fraktal menggunakan metode L-System adalah penentuan titik awal, menggambar dengan menggunakan segmen garis satu satuan garis, lalu menentukan komponen L-System yang terdiri dari sudut, aksioma, dan aturan produksi sehingga dapat dihasilkan bentuk fraktal yang sesuai [5]. Himpunan Julia dikonstruksi oleh persamaan pada bilangan kompleks [4]. Himpunan Julia dapat divisualisasi dengan variasi nilai $n$ dan nilai $c$ pada fungsi $f_{c}(z)=z^{n}+c$ serta jumlah iterasi pada pemrograman komputer [6]. Perubahan nilai $c$ dengan iterasi tetap menyebabkan motif fraktal semakin halus tetapi nilai $c=0$ motif fraktal hilang dan perbedaan nilai $n$ mempengaruhi himpunan Julia yang terbentuk, yaitu untuk nilai $n=2$ maka pola memiliki 2 kelopak, untuk $n=3$ maka pola memiliki 3 kelopak, dan untuk $n=4$ maka pola memiliki 4 kelopak dan berlaku untuk $n$ seterusnya [3].

Penelitian ini mengkaji visualisasi variasi motif songket Sambas menggunakan metode L-System dan himpunan Julia. Langkah - langkah pada penelitian, terlebih dahulu menentukan kain yang di teliti, dilanjutkan dengan mengidentifikasi motif kain songket Sambas tabur awan yang mendekati 
gambar fraktal. Kemudian melakukan perhitungan dari metode L-System dan himpunan Julia, untuk menghasilkan motif fraktal. Selanjutnya, motif fraktal yang terbentuk dari masing-masing metode $L$ System dan himpunan Julia, akan dilakukan visualisasi fraktal songket Sambas tabur awan dari kombinasi metode L-System dan himpunan Julia.

\section{FRAKTAL}

Fraktal adalah objek yang memiliki kemiripan dengan dirinya sendiri (self-similarity) dalam skala yang berbeda, artinya objek fraktal terdiri dari bagian-bagian yang memiliki sifat seperti objek tersebut. Setiap bagian objek bila diperbesar akan identik dengan objek tersebut [7]. Fraktal terbagi menjadi dua, yaitu fraktal alami dan fraktal buatan. Fraktal alami adalah fraktal yang terbentuk secara alami, seperti contoh dikehidupan sehari-hari daun pakis, dan aliran sungai. Sedangkan fraktal buatan merupakan hasil buatan manusia. Berdasarkan cara pendefinisian atau pembuatannya, fraktal dikelompokkan menjadi tiga, yaitu [3]:

1. Sistem fungsi teriterasi, contohnya adalah himpunan Cantor, karpet Sierpinski, kurva Peano, bunga salju Koch, kurva naga Harter-Heighway, Kotak T, dan spons Menger.

2. Fraktal waktu lolos, contohnya adalah himpunan Mandelbrot, himpunan Julia dan fraktal Lyapunov.

3. Fraktal acak, dihasilkan melalui proses stokastik, misalnya landskap fraktal .

Dalam geometri fraktal, fraktal adalah sebuah titik di dalam ruang metrik. Ruang metrik disimbolkan dengan $X$ yaitu himpunan tak kosong dari titik-titik yang disertai dengan fungsi $d: X \times$ $X \rightarrow \mathbb{R}$ yang mengukur jarak antara dua buah titik di ruang tersebut [7].

Berikut ini diberikan beberapa definisi yang berkaitan dengan ruang metrik.

Definisi 2.4.1 [8] Misalkan X adalah himpunan tak kosong. Metrik pada X adalah fungsi bernilai real $d: X \times X \rightarrow \mathbb{R}$ yang memenuhi sifat-sifat sebagai berikut :
N1. $d(x, y) \geq 0 \forall x, y \in X$
(Definit Positif)
N2. $d(x, y)=0$ jika dan hanya jika $x=y, \forall x, y \in X$
N3. $\quad d(x, y)=d(y, x), \forall x, y \in X$
(Simetris)
N4. $d(x, y) \leq d(x, z)+d(z, y), \forall x, y, z \in X$
(Ketaksamaan Segitiga)

Fungsi $d$ disebut sebagai metrik.

\section{HIMPUNAN JULIA}

Himpunan Julia merupakan salah satu contoh fraktal yang didefinisikan pada bilangan kompleks. Himpunan Julia dibangun dari iterasi-iterasi fungsi kompleks dengan dirinya sendiri. Fungsi yang membangun himpunan Julia adalah $f_{c}(z)=z^{n}+c$, dengan $z$ mempresentasikan sebuah variabel yang bisa juga termasuk semua nilai pada bidang kompleks berbentuk $x+y i$ untuk $x, y \in \mathbb{R}, c$ merupakan parameter bilangan kompleks $c=a+b i ; a, b \in \mathbb{R}$ yang tetap untuk himpunan Julia yang diberikan. Berikut ini diberikan bebrapa definisi yang berkaitan dengan himpunan Julia.

Definisi 2.5.1 [8] Diberikan $f_{c}=z^{2}+c, c \in \mathbb{C}$. Himpunan semua titik di $\mathbb{C}$ yang memuat orbit yang terbatas terhadap $f_{c}$ disebut himpunan Julia penuh yang dinotasikan dengan $k\left(f_{c}\right)$, yaitu $k\left(f_{c}\right)=$ $\left\{z \in \mathbb{C}: f_{C}^{n}(z)\right.$ terbatas $\}$,

Definisi 2.5.2 [8] Diberikan $f_{c}: \mathbb{C} \rightarrow \mathbb{C}$ dengan $f_{c}=z^{2}+c$. Batas dari himpunan Julia penuh disebut himpunan Julia, dan dinotasikan dengan $J\left(f_{c}\right)$.

Berikut ini diberikan teorema untuk membuktikan himpunan Julia bersifat invarian lengkap yang digunakan untuk mencari dimensi himpuanan Julia.

Teorema 2.5.3 [8] Himpunan Julia $J\left(f_{c}\right)$ bersifat invarian lengkap terhadap $f_{c}$.

Dimensi digunakan untuk mengukur, mendeskripsikan dan membandingkan suatu objek. Fraktal adalah objek yang memiliki dimensi bilangan real. Dimensi Minkowski Bouligand adalah salah satu metode perhitungan dimensi yang sering digunakan karena relatif lebih mudah dalam perhitungan. 
Dimensi Minskowski Bouligand dihitung menggunakan sifat invarian terhadap suatu pemetaan kontraktif, $f_{i}: \mathbb{R}^{n} \rightarrow \mathbb{R}^{n}$ dengan $i=1,2, \ldots, m$ di ruang metrik $(X, d)$ dan $c_{i}$ adalah konstanta kontraktif untuk $f_{i}$. Himpunan Julia bersifat invarian terhadap $f_{i}$ sehingga $\operatorname{dim}_{b}\left(J\left(f_{c}\right)\right)=$ $\operatorname{dim}_{h}\left(J\left(f_{c}\right)\right)=s$ untuk $c$ tertentu dengan memenuhi $\sum_{i=1}^{m} c_{i}^{S}=1[8]$.

Perhitungan himpunan Julia dicari dengan dimensi Minkowski Bouligand yang diawali dengan menentukan invers fungsi $f_{c}(z)=z^{n}+c$, setelah itu, tentukan sebarang jari-jari dengan maksimal $r(c)=\max (|c|, 2)$, maka akan diperoleh dimensi himpunan Julia untuk parameter $c$. Selanjutnya, input parameter $c$ ke program untuk menampilkan fraktal.

\section{L-SYSTEM}

L-System adalah sebuah metode penulisan kembali yang dilakukan secara berulang-ulang. Ide penulisan kembali pada dasarnya digunakan untuk membangun suatu objek komplek dari suatu objek sederhana, membangun objek komplek ini dengan cara mengganti secara bergantian bagian-bagian dari objek sederhana menggunakan seperangkat aturan penulisan kembali atau produksi [9]. L-System dibuat dengan suatu aksioma seperti satu segmen garis dan satu atau lebih aturan produksi, yang merupakan pernyataan seperti mengganti satu segmen garis dengan satu putaran ke kanan, mengganti satu segmen garis dengan satu putaran ke kiri dengan mengganti satu segmen garis dengan aturan lainnya [9]. Pengulangan pada aturan L-System merujuk kepada sebuah self similarity dan untuk itu bentuk fraktal dapat dibuat dengan mudah menggunakan L-System [11]. L-System dibagi menjadi beberapa komponen utama, yaitu [11]:

1. Huruf

Huruf adalah himpunan dari beberapa simbol variabel yang mengandung elemen yang dapat diganti demgam variabel lain. Huruf dinotasikan dengan $V$. misalnya dalam bentuk $V=\{a, b, c\}$ dan seterusnya, atau mungkin beberapa huruf lainnya.

2. Aksioma

Aksioma (inisiator) adalah suatu string $w$ dari simbol-simbol pada $V$. Aksioma dinotasikan dengan $w$, himpunan string $w$ dari $V$ dinotasikan dengan $V^{*}$. Jika diberikan $V=\{a, b, c\}$, maka beberapa contoh string yang dapat dibentuk yaitu $: a, b, c b$, aabca, $c a a b, b b c$, dan seterusnya. Panjang $|w|$ dari suatu string $w$ adalah jumlah simbol dalam string.

3. Produksi

Produksi adalah suatu pemetaan simbol $a \in V$ ke string $w \in V^{*}$. Produksi diberi label dan ditulis dengan notasi:

$$
p: a \mapsto w
$$

Jika suatu simbol $a \in V$ tidak memiliki aturan produksi maka dapat diasumsikan bahwa simbol tersebut dipetakan pada dirinya sendiri sehingga $a$ menjadi konstanta L-System [11].

\section{PENAFSIRAN GRAFIS PADA L-SYSTEM}

Pada $L$-System terdapat simbol-simbol yang dapat ditafsirkan secara grafis. Jika diasumsikan suatu satuan panjang $h$ dan perputaran sudut $\theta$, maka perintah-perintah dari simbol-simbol pada $L$ System adalah sebagai berikut [12]:

F : menggambar ke depan satu satuan sepanjang $h$.

G : bergerak ke depan satu satuan sepanjang $h$ tanpa harus menggambar

+ : berputar searah jarum jam dengan sudut $\theta$

- : berputar berlawanan jarum jam dengan sudut $\theta$

| : berputar $180^{\circ}$ atau berbalik arah

Jika diberikan aksioma dan aturan produksi dengan $V=\{F,+,-\}, w=F$ dan $p: F \rightarrow F-F+$ $F+F-F-F+F$, maka dimulai dengan aksioma $F$ akan diperoleh produksi iterasi pertama $g_{1}$ dengan string: 
Jika diasumsikan bahwa satu satuan sudut $\theta$ adalah $\frac{\pi}{2}$ radian maka penafsiran grafis dari geometri pertama dapat dilihat pada Gambar 1 [4].

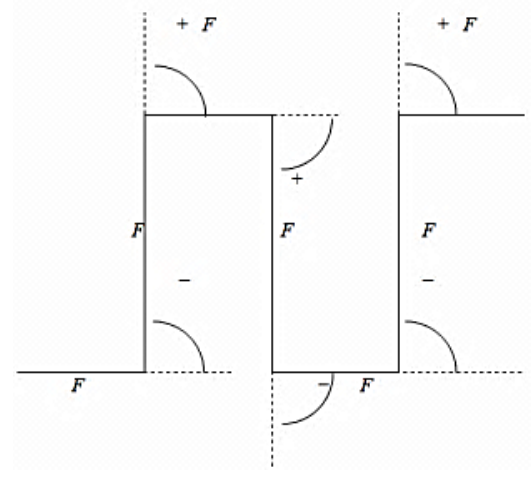

\section{Gambar 1. Penafsiran grafis dari L-System [4]}

Penafsiran grafis ini mula-mula mengerjakan perintah $F$ yaitu menggambar garis ke depan satu satuan sepanjang $h$. Perintah simbol (-) untuk memutar arahnya berlawanan arah jarum jam sebesar $=\frac{\pi}{2}$. Perintah berikutnya menggambar $F$ kembali sesuai arah yang telah ditentukan sebelumnya. Pada perintah simbol $(+)$ untuk memutar kembali arahnya searah jarum jam besarnya $\theta=\frac{\pi}{2}$. Kemudian menggambar $F$ kembali sesuai dengan arah yang baru. Perintah simbol $(+)$ untuk memutar kembali arahnya searah arah jarum jam sebesar $\theta=\frac{\pi}{2}$. Kemudian menggambar $F$ kembali sesuai dengan arah yang baru. Perintah simbol (-) untuk memutar arahnya berlawanan arah jarum jam sebesar $\theta=\frac{\pi}{2}$. Kemudian menggambar $F$ kembali sesuai dengan arah yang baru. Perintah simbol $(-)$ untuk memutar arahnya berlawanan arah jarum jam sebesar $\theta=\frac{\pi}{2}$. Kemudian menggambar $F$ kembali sesuai dengan arah yang baru. Pada perintah simbol $(+)$ untuk memutar kembali arahnya searah jarum jam besarnya $\theta=\frac{\pi}{2}$. Kemudian menggambar $F$ kembali sesuai dengan arah yang baru. Hal yang sama dapat dilakukan untuk menafsirkan grafis dari iterasi selanjutnya [4].

\section{VISUALISASI FRAKTAL SONGKET SAMBAS MENGGUNAKAN METODE L-SYSTEM DAN HIMPUNAN JULIA}

Berikut ini identifikasi kain songket Sambas untuk membagi metode yang akan digunakan pada Gambar 2.

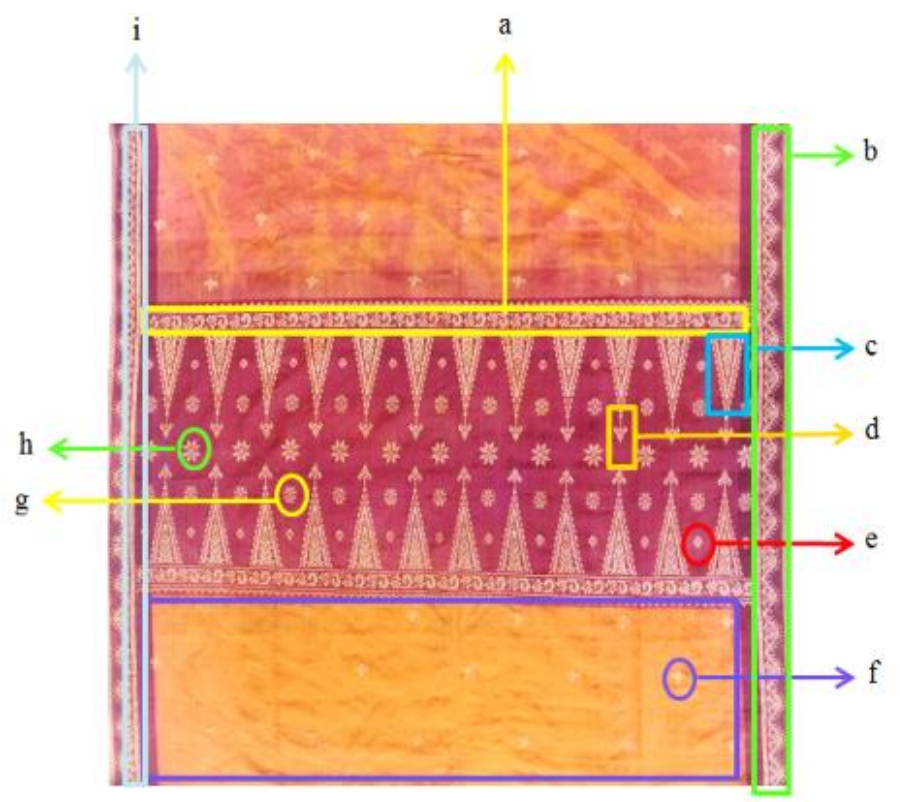

Gambar 2. Songket Sambas motif tabur awan

Identifikasi motif Songket Sambas berdasarkan pada cara pendefinisian atau pembuatan fraktal dapat dilihat pada Tabel 1. 
Tabel 1. Identifikasi motif songket Sambas

\begin{tabular}{|c|c|c|c|}
\hline $\begin{array}{c}\text { Kode } \\
\text { motif } \\
\text { Songket }\end{array}$ & $\begin{array}{l}\text { Motif songket } \\
\text { SambaS }\end{array}$ & $\begin{array}{c}\text { Gambar Fraktal yang mendekati } \\
\text { songket Sambas }\end{array}$ & Metode yang digunakan \\
\hline $\mathrm{a}$ & 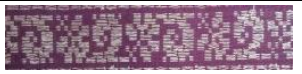 & Kurva naga [9] & L-System \\
\hline $\mathrm{b}$ & $60 \times$ & Kurva Koch [9] & L-System \\
\hline c & & Segitiga Sierpinski [9] & L-System \\
\hline d & b & Tree [9] & L-System \\
\hline $\mathrm{e}$ & & Koch island [9] & L-System \\
\hline $\mathrm{f}$ & 술 & Twin dragon [9] & L-System \\
\hline g & 漛 & thet & L-System \\
\hline $\mathrm{h}$ & 㗪 & 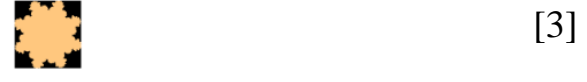 & Himpunan Julia \\
\hline $\mathrm{i}$ & 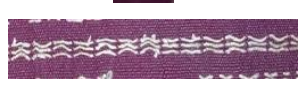 & Hilbert [9] & L-System \\
\hline
\end{tabular}

\section{A. Pembangkit Fraktal Motif Songket Sambas dengan metode L-System}

\section{Pembangkit Segitiga Sierpinski Motif Songket Sambas dengan Metode L-System}

Segitiga Sierpinski dapat dibangkitkan dengan menentukan komponen $L$-System [9]. Misal tentukan huruf $V=\{F, H,-\}$, aksioma $w=F-H-H$, serta produksi $p_{1}: F \mapsto F-H+F+H-F$ dan $P_{2}: H \mapsto H H$. Pada segitiga Sierpinski sudut yang diberikan adalah $120^{\circ}$. Penafsiran grafis yang dilakukan dari 5 iterasi dapat dilihat pada Gambar 3.

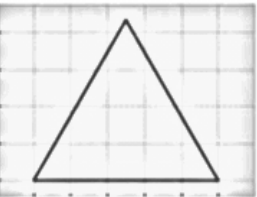

(a) Segitiga Sierpinski iterasi 0

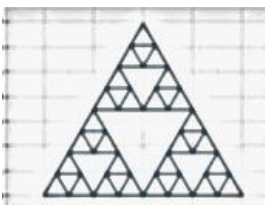

(d) Segitiga Sierpinski iterasi 3

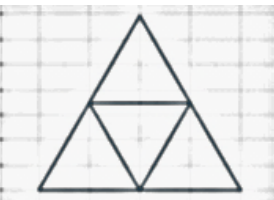

(b) Segitiga Sierpinski iterasi 1

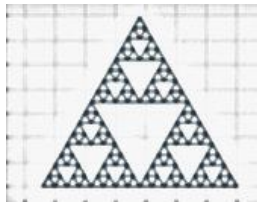

(e) Segitiga Sierpinski iterasi 4

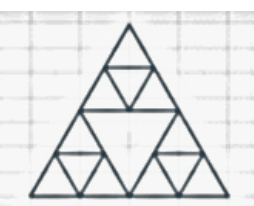

(c) Segitiga Sierpinski iterasi 2

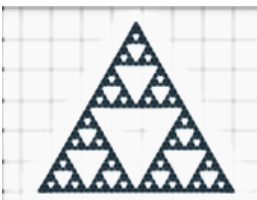

(f) Segitiga Sierpinski iterasi 5

\section{Gambar 3. Segitiga Sierpinski untuk beberapa iterasi}

\section{Pembangkit Kurva Naga Motif Songket Sambas dengan Metode $L$ - System}

Kurva naga dapat dibangkitkan dengan menentukan komponen L-System [9]. Misalkan huruf $V=\{F X, X, Y,+,-\}$, aksioma $w=F X$ serta produksi $p_{1}: X \mapsto X+Y F+$ dan $p_{2}: Y \mapsto-F X-$.Pada kurva Naga sudut yang diberikan adalah $90^{\circ}$. Penafsiran grafis yang dilakukan dari 5 iterasi dapat dilihat pada Gambar 4. 


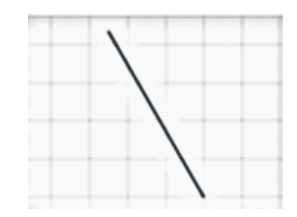

(a) Kurva naga iterasi 0

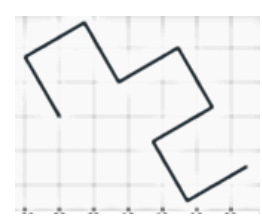

(d) Kurva naga iterasi 3

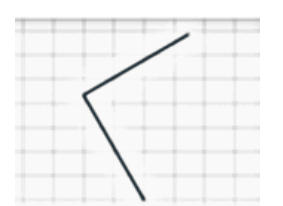

(b) Kurva naga iterasi 1

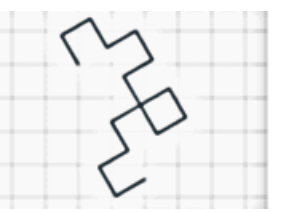

(e) Kurva naga iterasi 4

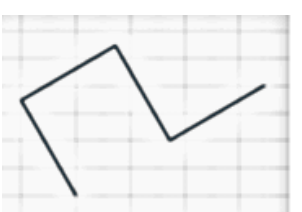

(c) Kurva naga iterasi 2

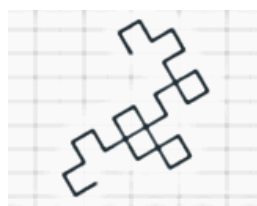

(f) Kurva naga iterasi 5

\section{Gambar 4. Kurva naga untuk beberapa iterasi}

\section{Pembangkit Kurva Koch Motif Songket Sambas dengan Metode L-System}

Kurva Koch dapat dibangkitkan dengan menentukan komponen L-System [9]. Misalkan huruf $V=\{F,+,-\}$, aksioma $w=F$ serta produksi $p: F \mapsto F+F-F+F$. Pada kurva Koch sudut yang diberikan adalah $90^{\circ}$. Penafsiran grafis yang dilakukan dari 5 iterasi dapat dilihat pada Gambar 5 .

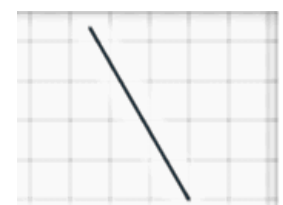

(a) Kurva Koch iterasi 0

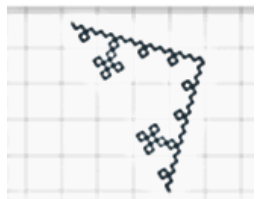

(d) Kurva Koch iterasi 3

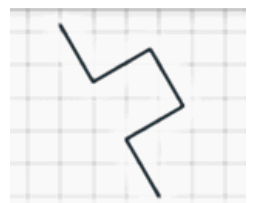

(b) Kurva Koch iterasi 1

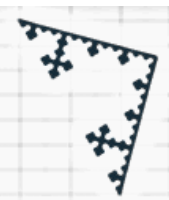

(e) Kurva Koch iterasi 4

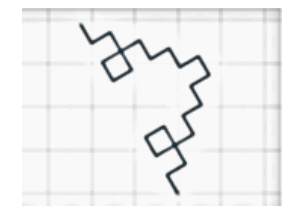

(c) Kurva Koch iterasi 2

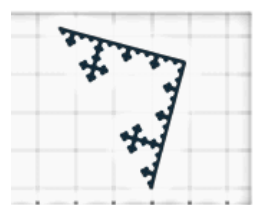

(f) Kurva Koch iterasi 5

\section{Gambar 5. Kurva Koch untuk beberapa iterasi}

\section{Pembangkit Tree Motif Songket Sambas dengan Metode L-System}

Tree dapat dibangkitkan dengan menentukan komponen L-System [9]. Misalkan huruf $V=$ $\{F, \mid,[],+,-\}$, aksioma $w=\mid X$ serta produksi $p_{1}: X \mapsto F[+X][-X] F X$, dan $p_{2}: \mathrm{F} 1 \mapsto \mathrm{FF}$. Pada tree sudut yang diberikan adalah $26^{\circ}$. Penafsiran grafis yang dilakukan dari 5 iterasi dapat dilihat pada Gambar 6.
(a) Tree iterasi 0
(b) Tree iterasi 1
(c) Tree iterasi 2
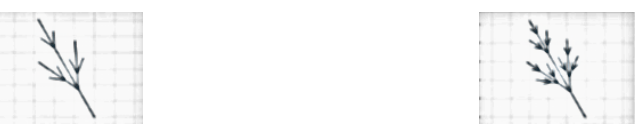
(d) Tree iterasi 3
(e) Tree iterasi 4
(f) Tree iterasi 5

\section{Gambar 6. Tree untuk beberapa iterasi}




\section{Pembangkit Koch Island Motif Songket Sambas dengan Metode L-System}

Koch Island dapat dibangkitkan dengan menentukan komponen L-System [9]. Misalkan huruf $V=\{F,+,-\}$, aksioma $w=F+F+F+F$ serta produksi $p: F \mapsto F F+-+++F+F$. Pada Koch Island sudut yang diberikan adalah $90^{\circ}$. Penafsiran grafis yang dilakukan dari 5 iterasi dapat dilihat pada Gambar 7.

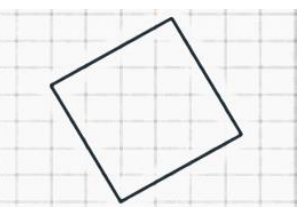

(a) Koch Island iterasi 0

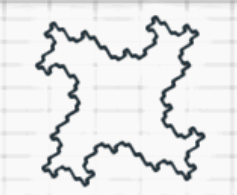

(d) Koch Island iterasi 3

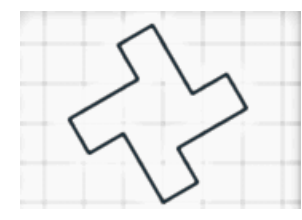

(b) Koch Island iterasi 1

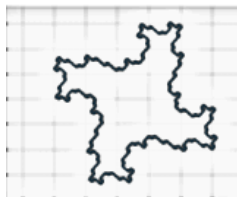

(e) Koch Island iterasi 4

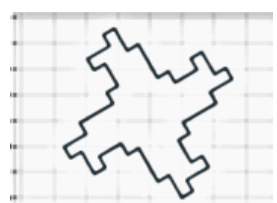

(c) Koch Island iterasi 2

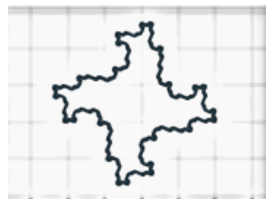

(f) Koch Island iterasi 5

Gambar 7. Koch Island untuk beberapa iterasi

\section{Pembangkit Rings Motif Songket Sambas dengan Metode $L$-System}

Rings dapat dibangkitkan dengan menentukan komponen L-System [9]. Misalkan huruf $V=$ $\{F,+,-\}$, aksioma $w=F-F-F-F-F$ serta produksi $p$ : $F \mapsto F-F++F+F-F-F$. Pada rings sudut yang diberikan adalah $72^{\circ}$. Penafsiran grafis yang dilakukan dari 5 iterasi dapat dilihat pada Gambar 8.

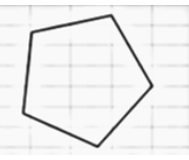

(a) Rings iterasi 0

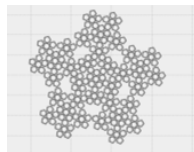

(d) Rings iterasi 3

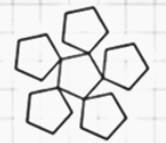

(b) Rings iterasi 1

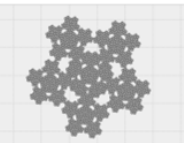

(e) Rings iterasi 4

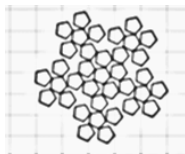

(c) Rings iterasi 2

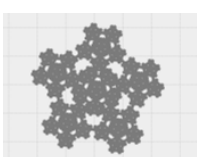

(f) Rings iterasi 5

\section{Gambar 8. Rings untuk beberapa iterasi}

\section{Pembangkit Hilbert Motif Songket Sambas dengan Metode L-System}

Hilbert dapat dibangkitkan dengan menentukan komponen L-System. Misalkan huruf $V=$ $\{X, Y, F,-,+\}$, aksioma $w=X$ serta produksi $p_{1}: X \mapsto+Y F-X F X-F X+$, dan $p_{2}: Y \mapsto-X F+$ $Y F Y+F X-$. Pada Hilbert sudut yang diberikan adalah $90^{\circ}$. Penafsiran grafis yang dilakukan dari 5 iterasi dapat dilihat pada Gambar 9.

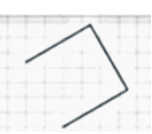

(b) Hilbert iterasi 1

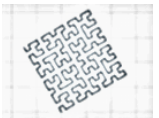

(f) Hilbert iterasi 4

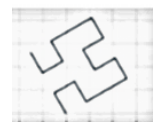

(c) Hilbert iterasi 2

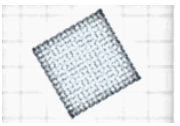

(e) Hilbert iterasi 5

(d) Hilbert iterasi 3

Gambar 9. Hilbert untuk beberapa iterasi 


\section{Pembangkit Twin Dragon Motif Songket Sambas dengan Metode L-System}

Twin dragon dapat dibangkitkan dengan menentukan komponen L-System [9]. Misalkan huruf $V=\{F, X, Y,-,+\}$, aksioma $w=F X+F X$ serta produksi $p_{1}: X \mapsto X+Y F$, dan $p_{2}: Y \mapsto F X-Y$. Pada twin dragon sudut yang diberikan adalah $90^{\circ}$. Penafsiran grafis yang dilakukan dari 5 iterasi dapat dilihat pada Gambar 10.

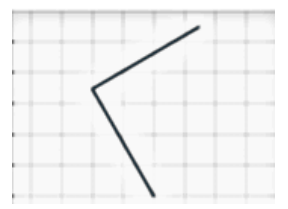

(a) Twin dragon iterasi 0

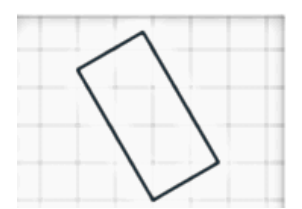

(b) Twin dragon iterasi 1

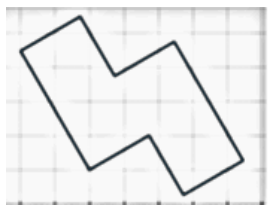

(c) Twin dragon iterasi 2

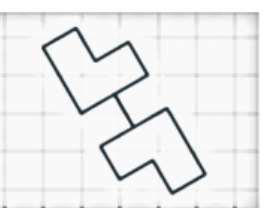

(d) Twin dragon iterasi 3

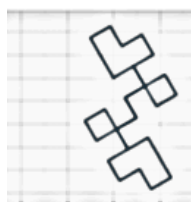

(e) Twin dragon iterasi 4

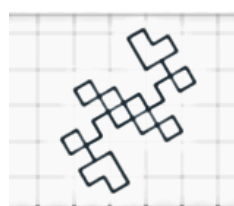

(f) Twin dragon iterasi 5

\section{Gambar 10. Twin Dragon untuk beberapa iterasi}

\section{B. Penghitungan Dimensi Fraktal Motif Songket Sambas dengan Himpunan Julia}

1. Penghitungan dimensi fraktal himpunan Julia untuk $f_{c}(z)=z^{n}+c$, dengan $n=8$

Himpunan Julia yang akan dihitung dimensinya adalah himpunan Julia untuk parameter $c$ yang besar. Diberikan langkah-langkah untuk menentukan dimensi fraktal himpunan Julia yaitu sebagai berikut:

a. Memisalkan $C$ adalah lingkaran dengan pusat 0 dan jari jari $|c|$.

Misalkan $C$ adalah lingkaran yang berpusat titik nol dan jari-jari $|c|, D$ adalah interior dari $C$, yaitu $D=\{z:|z|<|c|\}$.

b. Menentukan invers fungsi $f_{c}(z)=z^{n}+c$, dengan $n=8$.

$$
f_{c}(z)=z^{8}+c \text { atau } y=z^{8}+c
$$

Diperoleh invers dari fungsi $f_{c}(z)=z^{8}+c$ adalah $f_{c}^{-1}(z)=\sqrt[8]{z-c}$.

c. Memisalkan $S_{1}, S_{2}: D \rightarrow D$, dengan $S_{1}, S_{2}$ adalah himpunan bagian dari $f_{c}^{-1}(C)$ yang memetakan $D$ ke interior dari masing-masing lingkaran $f_{c}^{-1}(C)$.

Misalkan $S_{1}, S_{2}: D \rightarrow D$. Karena $f_{c}$ memetakan $f^{-1}(D)$ ke $C$ maka, $S_{1}$ dan $S_{2}$ adalah himpunan bagian dari $f_{c}^{-1}(C)$ yang memetakan $D$ ke interior dari masing-masing lingkaran $f_{c}^{-1}(C)$.

d. Memisalkan $V$ adalah lingkaran di dalam lingkaran $C$ yang berpusat di titik nol dan memiliki jari-jari minimum sedemikian sehingga memuat $f^{-1}(C)$.

e. Mengambil sebarang jari-jari minimum lingkaran $V$, batas maksimal jari-jari himpunan Julia $r(c)=\max (|c|, 2)$.

Misalkan $r_{\min }=|2 c|^{\frac{1}{8}}$, karena $V$ adalah bagian dari $D$, maka $S_{1}(V)$ dan $S_{2}(V)$ termuat pada masing-masing lingkaran $f_{c}^{-1}(C)$ yaitu

$$
\left|S_{1}\left(z_{1}\right)-S_{2}\left(z_{2}\right)\right|=\left|\left(z_{1}-c\right)^{\frac{1}{8}}-\left(z_{2}-c\right)^{\frac{1}{8}}\right|=\frac{\left.\left.\mid\left(z_{1}-c\right)^{\frac{2}{8}}\right)-\left(z_{2}-c\right)^{\frac{2}{8}}\right) \mid}{\left|\left(z_{1}-c\right)^{\frac{1}{8}}+\left(z_{2}-c\right)^{\frac{1}{8}}\right|}
$$

Pandang $\left|\left(z_{1}-c\right)^{\frac{1}{8}}+\left(z_{2}-c\right)^{\frac{1}{8}}\right|$, dengan ketaksamaan segitiga dimana $r=|c|$ dan $r_{\text {min }}=|2 c|^{\frac{1}{8}}$ maka diperoleh

$$
\left(|c|-|2 c|^{\frac{1}{8}}\right)^{\frac{1}{8}} \leq\left|z_{i}-c\right|^{\frac{1}{8}} \leq\left(|c|+|2 c|^{\frac{1}{8}}\right)^{\frac{1}{8}}
$$


Jadi untuk $\left|\left(z_{1}-c\right)^{\frac{1}{8}}+\left(z_{2}-c\right)^{\frac{1}{8}}\right|$ berlaku

$$
\begin{gathered}
\left(|c|-|2 c|^{\left.\frac{1}{8}\right)^{\frac{1}{8}}+\left(|c|-|2 c|^{\frac{1}{8}}\right)^{\frac{1}{8}}} \leq\left|\left(z_{1}-c\right)^{\frac{1}{8}}+\left(z_{2}-c\right)^{\frac{1}{8}}\right| \leq\left(|c|+|2 c|^{\frac{1}{8}}\right)^{\frac{1}{8}}+\left(|c|+|2 c|^{\frac{1}{8}}\right)^{\frac{1}{8}}\right. \\
2\left(|c|-|2 c|^{\left.\frac{1}{8}\right)^{\frac{1}{8}}} \leq\left|\left(z_{1}-c\right)^{\frac{1}{8}}+\left(z_{2}-c\right)^{\frac{1}{8}}\right| \leq 2\left(|c|+|2 c|^{\frac{1}{8}}\right)^{\frac{1}{8}}\right. \\
\frac{1}{2\left(|c|+|2 c|^{\frac{1}{8}}\right)^{\frac{1}{8}}} \leq \frac{1}{\left|\left(z_{1}-c\right)^{\frac{1}{8}}+\left(z_{2}-c\right)^{\frac{1}{8} \mid}\right|} \leq \frac{1}{2\left(|c|-|2 c|^{\frac{1}{8}}\right)^{\frac{1}{8}}} \\
\frac{1}{2\left(|c|+|2 c|^{\frac{1}{8}}\right)^{\frac{1}{8}}} \leq \frac{\left|S_{i}\left(z_{1}\right)-S_{i}\left(z_{2}\right)\right|}{\left|z_{1}-z_{2}\right|} \leq \frac{1}{2\left(|c|-|2 c|^{\frac{1}{8}}\right)^{\frac{1}{8}}} \\
\frac{1}{2\left(|c|+|2 c|^{\frac{1}{8}}\right)^{\frac{1}{8}}} \leq\left|S_{i}\left(z_{1}\right)-S_{i}\left(z_{2}\right)\right| \leq \frac{1}{2\left(|c|-|2 c|^{\frac{1}{8}}\right)^{\frac{1}{8}}} \\
\frac{1}{2}\left(|c|+|2 c|^{\left.\frac{1}{8}\right)^{-\frac{1}{8}}\left|z_{1}-z_{2}\right|} \leq\left|S_{i}\left(z_{1}\right)-S_{i}\left(z_{2}\right)\right| \leq \frac{1}{2}\left(|c|-|2 c|^{\frac{1}{8}}\right)^{-\frac{1}{8}}\left|z_{1}-z_{2}\right|\right.
\end{gathered}
$$

f. Menentukan nilai dimensi himpunan Julia untuk parameter $c$, dimana $s$ adalah dimensi dari himpunan Julia $\sum_{i=1}^{8} c_{i}^{S}=1$ dengan $c_{i}^{S}=\left(\frac{1}{2}\left(|c|+|2 c|^{\frac{1}{8}}\right)^{-\frac{1}{8}}\right)^{S}$

$$
\begin{aligned}
\sum_{i=1}^{8} c_{i}^{S} & =\sum_{i=1}^{8}\left(\frac{1}{2}\left(|c|+|2 c|^{\frac{1}{8}}\right)^{-\frac{1}{8}}\right)^{S} \\
1 & =8\left(\frac{1}{2}\left(|c|+|2 c|^{\frac{1}{8}}\right)^{-\frac{1}{8}}\right)^{S} \\
\frac{1}{8} & =\left(\frac{1}{2}\right)^{S}\left(|c|+|2 c|^{\frac{1}{8}}\right)^{-\frac{s}{8}} \\
\log \frac{1}{8} & =\log \left(\frac{1}{2}\right)^{S}\left(|c|+|2 c|^{\frac{1}{8}}\right)^{-\frac{s}{8}} \\
s & =\frac{8 \log 8}{\log \left(256\left(|c|+|2 c|^{\frac{1}{8}}\right)\right)}
\end{aligned}
$$

Diperoleh dimensi himpunan Julia adalah $s=\frac{8 \log 8}{\log \left(256\left(|c|+|2 c| \frac{1}{\overline{8}}\right)\right)}$.

Jadi, dimensi himpunan Julia untuk $0 \leq|c| \leq 1,5$ adalah $s=\frac{8 \log 8}{\log \left(256\left(|c|+|2 c|^{\frac{1}{8}}\right)\right)}$.

Dari perhitungan yang diperoleh, selanjutnya menginput nilai $n, x, y, a, b$ dari fungsi $f_{c}(z)=z^{n}+c$ ke program untuk menghasilkan fraktal.

\section{Hasil Visualisasi Variasi Songket Sambas dengan Metode L-System dan Himpunan Julia}

Hasil bahwa visualisasi fraktal songket Sambas menggunakan metode L-System dan himpunan Julia mendekati songket Sambas motif tabur awan. Terdapat sembilan motif fraktal yang diperoleh, yaitu dengan metode $L$-system diperoleh delapan motif dan satu motif himpunan Julia.

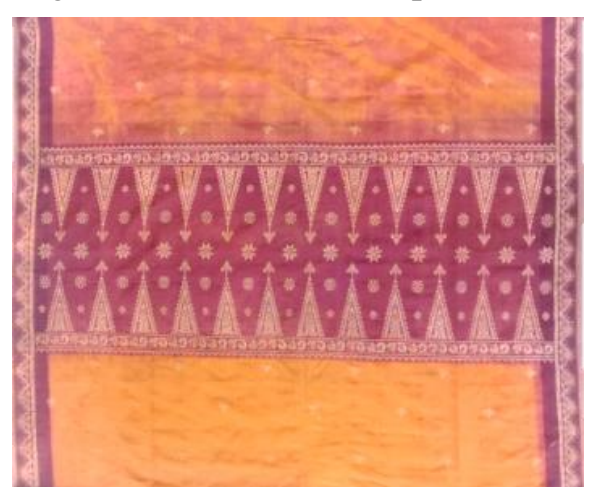

Gambar 11. Songket Sambas motif tabur awan

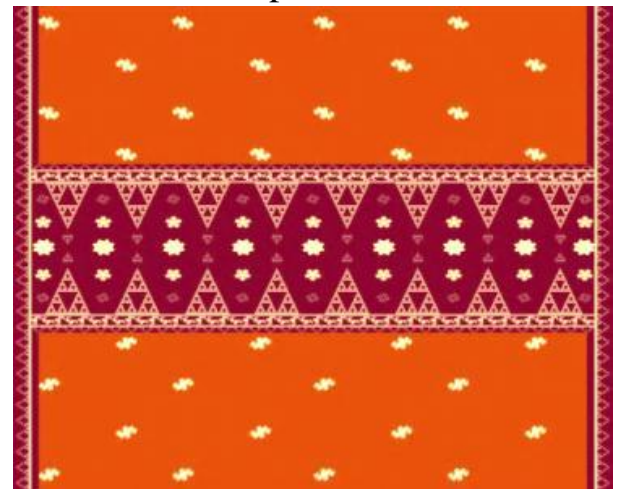

Gambar 12. Hasil visualisasi fraktal songket Sambas motif tabur awan 
Gambar 11 dan Gambar 12 menjelaskan perbandingan antara motif songket Sambas dan hasil visualisasi fraktal songket Sambas motif tabur awan. Perbedaan Gambar 11 dan Gambar 12, yaitu hasil pewarnaan fraktal pada proses visualisasi motif fraktal, sehingga ada beberapa gambar fraktal yang kurang jelas ketika divisualisasikan menggunakan bantuan program.

\section{KESIMPULAN}

Berdasarkan hasil dan pembahasan menggunakan metode L-System dan dimensi fraktal himpunan Julia $f_{c}(z)=z^{n}+c$, diperoleh kesimpulan sebagai berikut:

1. Langkah-langkah menggunakan metode L-System adalah dengan penerapan rumus iterasi pada setiap aksioma yang diberikan, sedangkan himpunan Julia menggunakan rumus iterasi pada fungsi yang diberikan.

2. Algoritma dengan metode L-System lebih sederhana bentuknya daripada algoritma himpunan Julia.

3. Visualisasi songket Sambas menggunakan metode L-System diperoleh delapan motif dan satu motif himpunan Julia.

\section{DAFTAR PUSTAKA}

[1] Novitasari, Candra. Songket Sambas Kalbar|Sejarah, Jenis, Motif, Fungsi, Gambar (Online). (https://pelajarindo.com/songket-sambas-kalbar-sejarah-jenis-motif-fungsi-gambar/, diakses tanggal 7 Agustus 2019); 2019.

[2] Addison, PS. Fractal and Chaos. Bristol and Pliladhelphia: Institute of Phisic Publising; 1997.

[3] Afriansyah, ME. Variasi Motif Batik Menggunakan Himpunan Julia Berdimensi Minkowski Bouligand. Skripsi FMIPA Universitas Sriwijaya; 2017.

[4] Nilawati, EP. Perbandingan Metode L-System dan Iterated Function System Dalam Membangkitkan Segitiga Sierpinski. Skripsi FMIPA Universitas Jember; 2015.

[5] Eka, YW. Pengembangan Desain Batik Labako dengan Menggunakan Geometri Fraktal Kurva Naga dan Corak Daun Tembakau. Jurnal Ilmu Dasar FMIPA Universitas Jember, 2(18): 125-132. 2017.

[6] Susanti, Eka. Variasi Motif Batik Palembang Menggunakan Sistem Fungsi Teriterasi dan Himpunan Julia. Jurnal Matematika FMIPA Universitas Sriwijaya, 5(1). 2015.

[7] Jauhari, Jaidan. Perangkat Lunak Pembangkit Geometri Fraktal Berbasis Fungsi Transenden. Pendidikan Matematika MIPA Universitas Sriwijaya, 1: 6-12. 2008.

[8] Murwani, T. Dimensi Fraktal Himpunan Julia. Jurusan Matematika Universitas Sanata Dharma, Yogyakarta. 2011

[9] P.Prusinkiewicz, dan A. Lindenmayer. The Algorithmic Beauty of Plants. New York: SpringerVerlag; 1990.

[10] Dickau, RM. Two-Dimensional L-System. 1996 (Online). (http://mathforum.org/advanced/robertd/lsys2d.html, di akses tanggal 5 Juni 2019)

[11] Manik, Ngarap Im, dan Manal. Penggunaan Model Fraktal Untuk Pengembangan Motif Ulos. Jurnal Mathematics \& Statistics Departement Binus University Jakarta Barat, 2(12); 143-151

[12] Mishra, J., dan Mishra, S. L-System Fraktal. Netherland: Elsevier; 2007.

NURUL FASEHA

HELMI

MARIATUL KIFTIAH
: Jurusan Matematika FMIPA Untan, Pontianak nurulfaseha42@student.untan.ac.id

: Jurusan Matematika FMIPA Untan, Pontianak helmi132205@yahoo.co.id

: Jurusan Matematika FMIPA Untan, Pontianak

kiftiahmariatul@math.untan.ac.id 